(107 pts) was formed of healthy blood donors and pts without presence of any signs of rheumatic or immune disease. There were $216(89 \%)$ women and $26(11 \%)$ men aged 10 to 80 years (mean $51.4 \pm 14.6$ yr.) in study group. RA group consisted of $158(65.3 \%)$ pts, SLE - of $53(21.9 \%)$ pts, and SS group of 31 $(12.8 \%)$ pts. Diagnosis was evaluated according to standard American Rheumatology Association criteria. Enzyme immunoassay test to detect aCL IgG was performed in all pts.

Results Presence of aCL IgG was found in 38 (15.7\%) pts out of 242 pts in the study group and in $6(5.6 \%)$ control group pts. The incidence of aCL IgG was $30.2 \%$ in SLE pts, $29 \%$ in SS pts, and $8.2 \%$ in RA pts. There was significant difference in aCL IgG frequency between study pts and control groups, $p=0.009$, and between SLE and SS pts and control pts as well $(\mathrm{p}=0.000014$ and 0.0002 , respectively). However, there was similar aCL IgG incidence in RA and control pts.

Age of pts with positive enzyme immunoassay (EIA) test was significantly lower as compared with negative EIA test pts (mean age $45.8 \pm 15.8$ yr. and $52.5 \pm 14.1$ yr., respectively, $\mathrm{p}=$ $0.009)$. However, this difference appeared to be significant in SLE pts only $(p=0.02)$.

There was no significant difference in aCL IgG incidence in separate subsets of pts either in respect to sex, or disease activity, course, or duration. In fact, some clinical manifestations were strongly associated with the presence of aCL IgG. There was significant difference in incidence of livedo reticularis, subacute vein thrombosis, and thrombocytopenia between pts with positive and negative EIA test $(\mathrm{p}=0.015,0.0066,0.001$, respectively).

The diagnosis of secondary antiphospholipid antibody syndrome (APS) was confirmed in $15(6.2 \%)$ pts. There were 11 $(20.7 \%)$ pts in SLE group, 2 (6.4\%) pts in SS group, and 2 $(1.3 \%)$ pts in RA group with this condition. The majority of those pts were aCL IgG - positive ( $\mathrm{p}=0,0001$, as compared with aCL IgG - negative APS pts).

Conclusion 1) Presence of aCL IgG was associated with some clinical manifestations such as livedo reticularis, subacute vein thrombosis, and thrombocytopenia, and antiphospholipid antibody syndrome in pts with systemic rheumatic diseases, 2) There was no association found between presence of aCL IgG and pts sex, disease activity, course, or duration.

\section{FRI0171 LEVELS OF SOLUBLE VCAM-1, P-SELECTIN, AND E- SELECTIN IN PATIENTS WITH PRIMARY ANTIPHOSPHOLIPID SYNDROME AND SYSTEMIC LUPUS ERYTEMATOSUS}

AA Novikov, EN Alexandrova, TM Reshetnyak. Clinical Immunology, Cardiology Research Center, Moscow, Russia

\subsection{6/annrheumdis-2001.240}

Background The antiphospholipid antibodies (aPL) are known to modify the expression of adhesion molecules on activated endothelial cells and platelets in vitro and in vivo.

\section{Objectives}

Methods We studied the levels of soluble (s) P-selectin, sE-selectin, and sVCAM-1 by ELISA in sera from 19 patients (pts) $(5$ male, 14 female, mean age? $36.9 \pm 10.1$ years) with primary antiphospholipid sindrome (PAPS), 23 pts (10 male, 13 female, mean age ? $35.3 \pm 11.6$ years) with systemic lupus (SLE) erythematosus? related antiphospholipid sindrome (SLE-APS), 15 pts
(13 male, 2 female, mean age? $29.0 \pm 9.0$ years) with SLE and 38 controls.

Results The sE-selectin and sVCAM-1 concentrations were significantly higher in pts with PAPS, SLE-APS and SLE compared with controls. $(78.3 \pm 61.2 \mathrm{ng} / \mathrm{ml} ; 52.3 \pm 14.1 \mathrm{ng} / \mathrm{ml} ; 70.5 \pm$ $46.9 \mathrm{ng} / \mathrm{ml}$ vs $38.0 \pm 13.4 \mathrm{ng} / \mathrm{ml}$; $=0.0019, \mathrm{p}=0.0363, \mathrm{p}=$ 0.0144 , respectively for sE-selectin; $1003 \pm 582.6 \mathrm{ng} / \mathrm{ml}$; $1189.6 \pm 691.0 \mathrm{ng} / \mathrm{ml} ; 1227 \pm 680.2 \mathrm{ng} / \mathrm{ml}$ vs $594.7 \pm 63.3$ $\mathrm{ng} / \mathrm{ml} ; \mathrm{p}=0.0001$ for $\mathrm{sVCAM}-1)$.

The sP-selectin concentration was significantly higher in pts with SLE compared with controls (262.4 $\pm 158.8 \mathrm{ng} / \mathrm{ml}$ vs $120.1 \pm 53.7 \mathrm{ng} / \mathrm{ml} ; \mathrm{p}=0.0037)$. Within the group of pts with PAPS the sP-selectin concentration was higher among those with ischaemic CNS involvement. ( $\mathrm{p}<0.02)$.

The serum C-reactive protein level was positively correlated with the sE-selectin concentration in SLE-APS $(\mathrm{r}=0.341, \mathrm{p}<$ $0.05)$ and SLE $(r=0.699, p<0.01)$, the sVCAM-1 concentration in PAPS $(\mathrm{r}=0.705, \mathrm{p}<0.001)$ and SLE $(\mathrm{r}=0.405, \mathrm{p}<$ $0.05)$.

The serum, anti ds and ssDNA antibody level was positively correlated with the sP-selectin concentration in SLE-APS $(\mathrm{r}=$ 0.730 , and $\mathrm{r}=0.909, \mathrm{p}<0.001$ ), and the sE-selectin concentration in SLE $(r=0.684, p<0.001$ and $r=0.616, p<$ $0.002)$.

Conclusion The sE-selectin and sVCAM-1 concentrations were significantly higher in pts with PAPS, SLE-APS and SLE compared with controls. $(78.3 \pm 61.2 \mathrm{ng} / \mathrm{ml} ; 52.3 \pm 14.1 \mathrm{ng} / \mathrm{ml}$; $70.5 \pm 46.9 \mathrm{ng} / \mathrm{ml}$ vs $38.0 \pm 13.4 \mathrm{ng} / \mathrm{ml} ; \mathrm{p}=0.0019, \mathrm{p}=$ $0.0363, \mathrm{p}=0.0144$, respectively for sE-selectin; $1003 \pm 582.6$ $\mathrm{ng} / \mathrm{ml} ; 1189.6 \pm 691.0 \mathrm{ng} / \mathrm{ml} ; 1227 \pm 680.2 \mathrm{ng} / \mathrm{ml}$ vs $594.7 \pm$ $63.3 \mathrm{ng} / \mathrm{ml} ; \mathrm{p}=0.0001$ for sVCAM-1).

The sP-selectin concentration was significantly higher in pts with SLE compared with controls $(262.4 \pm 158.8 \mathrm{ng} / \mathrm{ml}$ vs $120.1 \pm 53.7 \mathrm{ng} / \mathrm{ml} ; \mathrm{p}=0.0037)$. Within the group of pts with PAPS the sP-selectin concentration was higher among those with ischaemic CNS involvement $(\mathrm{p}<0.02)$.

The serum C-reactive protein level was positively correlated with the sE-selectin concentration in SLE-APS $(r=0.341, p<$ $0.05)$ and SLE $(r=0.699, \mathrm{p}<0.01)$, the sVCAM-1 concentration in PAPS $(\mathrm{r}=0.705, \mathrm{p}<0.001)$ and SLE $(\mathrm{r}=0.405, \mathrm{p}<$ $0.05)$.

The serum, anti ds and ssDNA antibody level was positively correlated with the sP-selectin concentration in SLE-APS $(\mathrm{r}=$ 0.730 , and $\mathrm{r}=0.909, \mathrm{p}<0.001)$, and the sE-selectin concentration in SLE $(r=0.684, p<0.001$ and $r=0.616, p<$ $0.002)$.

\section{FRI0172 LONG-TERM FOLLOW-UP OF PAEDIATRIC PATIENTS WITH POSITIVE ANTI-PHOSPHOLIPID ANTIBODIES}

A Ince, A Roumany, U Daud, PH Pepmueller, TL Moore. Internal Medicine/Rheumatology, St Louis University Health Sciences Center, St Louis, USA

\subsection{6/annrheumdis-2001.241}

Background Long-term outcome data of Anti-Phospholipid syndrome (APLS) in paediatric patient population is very limited. There are no established criteria for making a diagnosis of Paediatric Anti- Phospholipid syndrome (APLS). Adult APLS criteria includes the major criteria of fetal loss, which is not pertinent to the pedriatric population.

Objectives To evaluate the clinical outcome of paediatric patients who either had a positive Lupus Anticoagulant (LAC), 